\title{
Giant landslide triggerings and paleoprecipitations in the Central Western Andes: The aricota rockslide dam (South Peru)
}

\author{
Fabrizio Delgado ${ }^{a, b, c}$, Swann Zerathe ${ }^{\mathrm{b}, *}$, Laurence Audin ${ }^{\mathrm{b}}$, Stéphane Schwartz ${ }^{\mathrm{b}}$, \\ Carlos Benavente $^{\mathrm{c}}$, Julien Carcaillet ${ }^{\mathrm{b}}$, Didier L. Bourlès ${ }^{\mathrm{d}}$, Aster Team ${ }^{\mathrm{d}, 1}$ \\ a Especialidad Ingeniería Geológica, Facultad de Ciencias e Ingeniería. Pontificia Universidad Católica del Perú, Av. Universitaria 1801, San Miguel, Lima \\ 15088, Perú \\ ${ }^{\mathrm{b}}$ Univ. Grenoble Alpes, Univ. Savoie Mont Blanc, CNRS, IRD, IFSTTAR, ISTerre, 38000 Grenoble, France \\ c Instituto Geológico, Minero y Metalúrgico INGEMMET, Av. Canadá 1470, Lima, Perú \\ d Aix-Marseille Univ., CNRS, IRD, Coll. France, UM 34 CEREGE, Technopôle de l'Environnement Arbois-Méditerranée, BP80, 13545 Aix-en-Provence, France
}

\section{A R T I C L E I N F O}

\section{Article history:}

Received 5 February 2019

Received in revised form 15 October 2019

Accepted 30 October 2019

Available online 2 November 2019

\section{Keywords:}

Giant landslide dam

Central Western Andes

${ }^{10}$ Be dating

Triggering factors

\begin{abstract}
A B S T R A C T
The central part of the Western Andes holds an exceptional concentration of giant paleolandslides involving very large volumes of rock material $\left(\mathrm{v}>\mathrm{km}^{3}\right)$. While those gravitational slope failures are interpreted consensually as an erosional response to the geodynamic activity of the Andes (relief formation and tectonic activity), the question of their triggering mechanisms remains enigmatic. To clarify the respective roles of climatic versus seismic forcing on the Andean landslides, new temporal constraints on paleo movements are essential. Here, we focus on one of those giant slope failures, the Aricota giant rockslide that damned the Locumba valley in southern Peru. We conducted fieldwork, high-resolution DEM analysis and cosmogenic nuclide dating to decipher its development history and failure mechanisms. Our results point to the occurrence of two successive events. A giant failure mobilizing a rock volume of ca. $2 \mathrm{~km}^{3}$ first produced a dam at $17.9 \pm 0.7 \mathrm{ka}$. Considering its height of ca. $600 \mathrm{~m}$, the Aricota rockslide dam is one of the three largest landslide dams worldwide. At $12.1 \pm 0.2 \mathrm{ka}$, a second event produced ca. 0.2 $\mathrm{km}^{3}$ of material, and the rock-avalanche debris spread out over the dam. As the chronology of those two events is pointing to the two main paleoclimatic pluvial periods in this region (Heinrich Stadial 1a and Younger Dryas), we favor the interpretation of a climatic forcing. At a regional scale, the concomitant aggradation of alluvial terraces and fan systems along the nearby valleys highlights higher regional erosion, sediments supply and mass-wasting events during those paleoprecipitation events and strengthens this conclusion.
\end{abstract}

(c) 2019 Elsevier B.V. All rights reserved.

\section{Introduction}

The Western flank of the Central Andes (south Peru - north Chile) holds one of the most exceptional concentrations of giant landslides worldwide (Crosta et al., 2014). Those gravitational instabilities mobilize large volume of rock material $\left(>10^{9} \mathrm{~m}^{3}\right)$, with debris propagation over long distance $\left(>10^{3} \mathrm{~m}\right)$ affecting the Western Cordillera from elevations between $4500 \mathrm{~m}$ to sea level (e.g. Wörner et al., 2002; Strasser and Schlunegger, 2005; Pinto et al., 2008; Crosta et al., 2014). This Andean area is particularly active geodynamicaly, related to the long-term convergence between the Nazca and the South America plates. The global shortening is associated

\footnotetext{
* Corresponding author.

E-mail address: swann.zerathe@ird.fr (S. Zerathe).

1 Georges Aumaître and Karim Keddadouche.
}

with the relief construction, producing instantaneous deformation (crustal seismicity) coupled with long-term processes of surface uplift and volcanism (Thouret et al., 2017; Benavente et al., 2017). In this region, the large-scale landsliding is suspected to be an efficient relief erosion mechanism at regional scale (Mather et al., 2014).

Additionally, the Western Andean flank presents a climatic setting marked by a dominant hyper-aridity persisting at least since 20 million years (e.g. Dunai et al., 2005). This particular climate environment, with very low denudation rates (typically 1-10 mm.kyr ${ }^{-1}$; Nishiizumi et al., 2005; Madella et al., 2018), allows the local preservation of landscape over hundreds of thousands years (e.g. Zerathe et al., 2017). This offers a unique opportunity to track gravitational slope processes over a temporal scale currently unknown, close to the timing of the orogen evolution (Hermanns et al., 2001). 